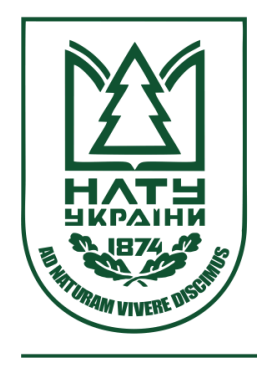

Науковий вісник НлтУ України

Scientific Bulletin of UNFU

https://nv.nltu.edu.ua

https://doi.org/10.36930/40300203

$@ \bowtie$ Correspondence author

Article received 02.03.2020 p.

Article accepted 04.06.2020 p.

N. Ye. Horbenko

UDC 581.19:582.926.4:632.4

nata.horbenko@gmail.com

Н. Я. Левчик', Г. І. Скрипка' ${ }^{1}$ В. Ф. Левон ${ }^{1}$, О. В. Закрасов ${ }^{1}$, Н. Є. Горбенко

${ }^{I}$ Начіональний ботанічний сад ім. М. М. Гришка НАН Украйни, м. Київ, Украйна

${ }^{2}$ Начіональний лісотехнічний університет Украӥни, м. Львів, Украӥна

\title{
ВМІСТ БIОХIМІЧНИХ РЕЧОВИН У РОСЛИН PHLOX PANICULATA L. В УМОВАХ ЛІСОСТЕПУ УКРАЇНИ
}

\begin{abstract}
Досліджено питання стійкості декоративних рослин Phlox paniculata L. до біотичного стресу. За результатами дослідження листків рослин 11 сортів Phlox paniculata з різним ступенем ураження збудником борошнистої роси (Erysiphe cichoracearum DC.f. phlogis Jacz.) визначено кількісний вміст біохімічних речовин (проліну, катехінів, флавонолів та антоціанів) в умовах Лісостепу України. Виявлено, що рослини, уражені збудником борошнистої роси, характеризувалися нижчим рівнем флавонолів (сорти 'Poliarnyi' - 0,268 мг/г, 'Mohuchii' - 0,354 мг/г), неуражені - вищим вмістом (сорти 'Моһuchii' 0,729 мг/г та 'Fiosin' - 0,719 мг/г). Окрім цього, встановлено тенденцію до істотного збільшення вмісту катехінів у цілому на $8-21 \%$ в уражених борошнистою росою рослин, порівняно із неураженими. Відзначено певну закономірність щодо вмісту антоціанів: в уражених рослин він був на $18-48$ \% вищим, ніж у неуражених. Зроблено висновок, що вторинні метаболіти $\epsilon$ маркерами відповідної реакції та стійкості рослинного організму до стресу різного походження, оскільки під дією стресу, спричиненого збудником борошнистої роси, збільшується вміст флавонолів, катехінів та антоціанів. На відміну від інших показників, рівень проліну істотно не залежить від ступеня ураженості рослин Phlox paniculata збудником борошнистої роси, оскільки в цьому механізмі захисту рослин від стресу, спричиненого збудником борошнистої роси, діє інший механізм із залученням вторинних метаболітів.
\end{abstract}

Ключові слова: Phlox paniculata L. - флокс волотистий, збудник борошнистої роси; пролін; катехіни; флавони; флавоноли; антоціани; стійкість.

Вступ. Рід Phlox L., за системою А. Л. Тахтаджяна [21], належить до порядку Polemoniales, родини Polemaniaceae L. de Jussieu (Синюховi). Майже всі види роду - ендеміки Північної Америки, поширені між $30 \mathrm{i}$ 50 паралелями, винятком є Phlox sibirica L., який росте у Західному й Східному Сибіру [10]. Світова флора роду Phlox L. налічує близько 65 видів, з яких тільки понад 20 використовують у ландшафтному будівництві. Найвідоміший у культурі - флокс волотистий (Phlox paniculata L.), який виник унаслідок складної міжвидової та міжсортової гібридизації. Іноді його називають флокс садовий (Phlox hortorum). За різними даними, у світі зареєстровано від 2000 до 3000 [2, 6, 8, 15]. У Державному реєстрі сортів рослин, придатних для поширення в Україні, на 2019 р. наявні 12 сортів Phlox paniculata L. Серед них 3 дослідні сорти - 'Holubka', 'Novinka', 'Panianka'.

Phlox paniculata L. - флокс волотистий, поширений

на сході Північної Америки (басейн р. Міссісіпі), у США, у штатах від Нью-Йорка до Джорджії, і на захід до Іллінойсу і Арканзасу. Багаторічна короткокореневищна трав'яна рослина, заввишки від 50-60 до $150 \mathrm{~cm}$. Стебла прямі, міцні, неопушені, здерев'янілі при основі. Листки овально-ланцетоподібні, неопушені, від 1,5 до 4 см завширшки та від 5-7 до 15 см завдовжки, супротивні, по два у кожному вузлі. Розташування листків на стеблі має певну особливість - кожна наступна пара листків розміщена відносно попередньої хрестоподібно 3 поворотом на $90^{\circ}[2,5]$.

Успішність інтродукції квітниково-декоративних рослин, зокрема Phlox paniculata L., визначається багатьма показниками, серед яких важливе місце посідають декоративні та господарсько-біологічні особливості, ступінь прояву яких істотно залежить від функціонального стану рослин під час вегетації, що проявляється у біохімічних показниках рослин. Літературних

Інформація про авторів:

Левчик Наталія Яківна, канд. біол. наук, наук. співробітник, відділ культурної флори. Email: levchyk.n@ukr.net; https://orcid.org/0000-0001-8668-8763

Скрипка Ганна Іванівна, канд. біол. наук, наук. співробітник, відділ квітниково-декоративних рослин. Email: anna_skripka@bigmir.net

Левон Володимир Федорович, канд. хім. наук, ст. науковий співробітник, відділ акліматизації плодових культур. Email: vflevon@gmail.com; https://orcid.org/0000-0003-2652-9984

Закрасов Олександр Володимирович, канд. біол. наук, наук. співробітник, відділ алелопатії. Email: tombarry1977@gmail.com

Горбенко Наталія Євгенівна, канд. с.-г. наук, доцент, кафедра ботаніки, деревинознавства та недеревних ресурсів лісу. Email: nata.horbenko@gmail.com; https://orcid.org/0000-0002-6053-6582

Цитування за ДСтУ: Левчик Н. Я., Скрипка Г. І., Левон В. Ф., Закрасов О. В., Горбенко Н. Є. Вміст біохімічних речовин у рослин Phlox paniculata L. в умовах Лісостепу України. Науковий вісник НЛтУ України. 2020, т. 30, № 2. С. 19-23.

Citation APA: Levchyk, N. Ya., Skrypka, H. I., Levon, V. F., Zakrasov, O. V., \& Horbenko, N. Ye. (2020). The content of biochemical substances in Phlox paniculata L. plants leaves in the Forest-steppe zone of Ukraine. Scientific Bulletin of UNFU, 30(2), 19-23. https://doi.org/10.36930/40300203

Науковий вісник НЛТУ України, 2020, т. 30, № 2

Scientific Bulletin of UNFU, 2020, vol. 30, no 2 
даних про результати досліджень із встановлення ролі біохімічних речовин у стійкості рослин $P h$. paniculata виявлено не було. Тому визначення кількості флавоноїдів, зокрема флавонолів, проліну, катехінів та антоціанів, як показників стійкості у рослин Ph. paniculata до патогенів, є актуальним.

Об'єкт дослідження - нові та старі сорти вітчизняної й іноземної селекції колекційного фонду Національного ботанічного саду ім. М. М. Гришка НАН України з різним ступенем ураження збудником борошнистої роси (гриб Erysiphe cichoracearum DC. f. phlogis Jacz.): 'Rembrandt', 'Katharine', 'Fujiyama', 'Mohuchii', 'Detstvo', 'Fiosin', 'Holubka', 'Panianka', 'Poliarnyi', 'Tenor', 'Novinka'.

Мета роботи - дослідити біохімічні показники у листках рослин Phlox paniculata L., уражених і неуражених збудником борошнистої роси (Erysiphe cichoracearum DC.f. phlogis Jacz.) в умовах Лісостепу України.

Для досягнення зазначеної мети потрібно виконати такі завдання дослідження:

- встановити вміст флавонолів, які є маркером стійкості рослин до ураження збудником борошнистої роси;

- виявити динаміку вмісту катехінів в уражених борошнистою росою рослин порівняно із неураженими;

- відзначено певну закономірність щодо вмісту антоціанів в уражених рослин порівняно з неураженими;

- встановити рівень проліну, який залежить від ступеня ураженості рослин Phlox paniculata збудником борошнистої роси.

Наукова новизна роботи полягає у тому, що вперше було виявлено тенденцію до істотного збільшення вмісту катехінів в уражених борошнистою росою рослин, порівняно із неураженими. Також було відзначено певну закономірність щодо вмісту антоціанів: в уражених рослин він був на 18-48 \% вищим, ніж у неуражених..

Практична значущість отриманих результатів полягає у тому, що визначений рівень проліну істотно не залежить від ступеня ураженості рослин Phlox paniculata збудником борошнистої роси, оскільки в механізмі захисту рослин від стресу діє застосування вторинних метаболітів.

Матеріали і методи дослідження. Для лабораторних досліджень згідно з методикою відбирали листки рослин на ділянці відкритого грунту. Вміст флавоноїдів у перерахунку на рутин визначали відповідно до методики В. Ю. Андреєвої та Г. І. Калінкіної [1]. Вміст антоціанів і катехінів визначали за вказівками В. І. Кривенцова [9]. Рівень проліну визначали за методикою визначення проліну в рослинних об'єктах [18].

Обговорення отриманих результатів. Для рослин сортів Phlox paniculata L., незалежно від місця культивування, значною проблемою є стійкість до ураження збудниками хвороб [4], зокрема до борошнистої роси (гриб Erysiphe cichoracearum D. C. f. phlogis Jacz.) [17], що негативно позначається на декоративності та функціональному стані рослин під час вегетаційного періоду [12].

Постає питання, завдяки яким фізіологічним механізмам та біохімічним сполукам підтримується той чи інший рівень стійкості у рослин. Останнім часом набув розвитку новий напрям молекулярних досліджень біологічних об'єктів - метаболоміка, що нині інтенсивно розвивається й надає можливості комплексного аналізу метаболітів, як первинних, так і вторинних. 3 погляду метаболоміки для процесів адаптації рослин важливі три різні типи сполук: 1) речовини, що беруть участь у процесі аклімації, такі як антиоксиданти, осмопротектори; 2) побічні продукти стресу, які з'являються у клітинах через порушення нормального гомеостазу внаслідок зміни умов зростання; 3) сигнальні молекули, що безпосередньо включаються у відповідь на аклімацію рослин.

Серед відомих рослинних метаболітів, які є відповідною реакцією рослини на біотичний або абіотичний стрес, чільне місце належить амінокислотам (пролін, аланін), які виконують функцію осмопротекторів для захисту рослин під час сольового стресу, посухи, зневоднення [14]. Накопичення проліну допомагає рослинам адаптуватися до несприятливих умов, захищаючи від інактивації білки, ДНК, цілий ряд ферментів та інших важливих клітинних компонентів [18].

В умовах водного стресу, внаслідок посухи або високого вмісту солей у грунті, рослини нагромаджують дуже велику кількість проліну в листках, який захищає рослинні клітини від зневоднення, оскільки він, на відміну від мінеральних солей, не виявляє інгібуючого впливу навіть у дуже високих концентраціях [7].

Сполуки ж вторинного метаболізму, на відміну від первинних метаболітів, потрібні клітині в малих кількостях, властиві диференційованим рослинним клітинам лише спеціалізованих органів і тільки у певні фази розвитку рослини, мають функціональне значення не на рівні клітини, а на рівні цілої рослини. Частіше за все ці речовини виконують "екологічні функції", тобто захищають рослину від різних шкідників і патогенів, беруть участь у розмноженні рослин, надаючи забарвлення i запаху квітам і плодам, забезпечують взаємодію рослин між собою і з іншими організмами в екосистемі. Для вторинних метаболітів характерними є видова спеціалізація, біологічна активність, відносно невелика молекулярна маса (2-3 кДа), синтез із невеликої кількості вихідних сполук [10].

Важливо наголосити, що стійкість рослин до хвороб - генетично детермінована. Аналіз біохімічної та фізіологічної реакцій рослинного організму на біотичні та абіотичні фактори свідчить про те, що відбувається адаптаційний процес, суть якого полягає у специфічній адекватній реакції організму із підвищенням стійкості до пошкоджувального фактора [16].

Молекули можуть бути сигнальними молекулами активації системного захисту та відповіді у процесі аклімації рослин. Їхня присутність може слугувати важливим інструментом виявлення таких метаболітів для ідентифікації біологічних молекул, які з'являються на пізніших етапах за умов стресу [14]. Перші результати досліджень попередньо вже було висвітлено у тезах конференцій $[13,19,20]$.

Флавоноли як і флавони належать до жовтих фарбуючих сполук рослин, які здавна застосовувались для фарбування тканин. Однією із характерних особливостей флавонолів $є$ утворення полігідроксилированих та поліметоксилированих сполук. Це зокрема кверцетагетин та дигицитрин. У тканинах рослин флавоноли звичайно присутні у вигляді глікозидів [22].

Важливо, що флавоноли поглинають світло у більш короткохвильовій частині спектра (280-320 нм), ніж антоціани. Зважаючи на це однією 3 головних функцій флавонів i флавонолів $є$ захист рослинних тканин (найперше, епідермальних) від ультрафіолетової радіації. Завдяки цьому клітини епідермісу листків, пропус- 
каючи 70-80 \% видимого світла, здатні затримувати до 95 \% ультрафіолетового випромінювання. Окрім цього, флавоноїди можуть функціонувати як сигнальні сполуки при взаємодії з мікроорганізмами. Також флавоноїди використовуються рослинними організмами для захисту від травоїдних тварин та відіграють важливу роль в імунітеті рослин (фітоалексини) [7].

Для порівняльного аналізу брали уражені і не уражені збудником борошнистої рослин листки рослин Phlox paniculata колекційного фонду відділу квітниково-декоративних рослин.

Серед неуражених рослин найменший вміст флавонолів $(0,365 \mathrm{мг/ \Gamma )} \mathrm{відзначено} \mathrm{у} \mathrm{рослин} \mathrm{сорту} \mathrm{'Detstvo',}$ найвищий - у сорту 'Mohuchii' $(0,729$ мг/г) (табл. 1). Ceред рослин, уражених збудником борошнистої роси, найменше флавонолів виявлено у сорту 'Poliarnyi' 0,268 мг/г, найбільше - у сорту 'Novinka' - 0,493 мг/г (див. табл. 1).

Табл. 1. Кількісний вміст флавонолів, катехінів та антоціанів у рослин Phlox paniculata, неуражених збудником борошнистої роси

\begin{tabular}{|c|c|c|c|}
\hline Сорт & $\begin{array}{c}\text { Сумарний } \\
\text { вміст флавоно-- } \\
\text { лів, мг/г (суха } \\
\text { вага) }\end{array}$ & $\begin{array}{c}\text { Вміст катехі- } \\
\text { нів, мг/100 г } \\
\text { сухої речови- } \\
\text { ни }\end{array}$ & $\begin{array}{c}\text { Вміст антоціанів, } \\
\text { мг/100 г сухої } \\
\text { речовини }\end{array}$ \\
\hline 'Katharine' & $0,504^{ \pm 0,010}$ & $126,00^{ \pm 2,68}$ & $63,00^{ \pm 0,12}$ \\
\hline 'Panianka' & $0,676^{ \pm 0,012}$ & $75,00^{ \pm 1,66}$ & $54,00^{ \pm 0,11}$ \\
\hline 'Tenor' & $0,569^{ \pm 0,011}$ & $51,00^{ \pm 1,34}$ & $66,00^{ \pm 0,16}$ \\
\hline 'Poliarnyi' & $0,697^{ \pm 0,014}$ & $114,00^{ \pm 2,82}$ & $52,50^{ \pm 0,11}$ \\
\hline 'Fiosin' & $0,719^{ \pm 0,019}$ & $96,00^{ \pm 2,26}$ & $66,00^{ \pm 0,14}$ \\
\hline 'Mohuchii' & $0,729^{ \pm 0,016}$ & $123,00^{ \pm 2,64}$ & $63,00^{ \pm 0,13}$ \\
\hline 'Rembrandt' & $0,601^{ \pm 0,016}$ & $99,00^{ \pm 2,16}$ & $72,00^{ \pm 0,15}$ \\
\hline 'Holubka' & $0,644^{ \pm 0,017}$ & $82,50^{ \pm 1,86}$ & $45,00^{ \pm 0,10}$ \\
\hline 'Novinka' & $0,536^{ \pm 0,012}$ & $138,00^{ \pm 3,12}$ & $66,00^{ \pm 0,13}$ \\
\hline 'Fujiyama' & $0,515^{ \pm 0,013}$ & $96,00^{ \pm 2,13}$ & $55,50^{ \pm 0,11}$ \\
\hline 'Detstvo' & $0,365^{ \pm 0,003}$ & $147,00^{ \pm 3,32}$ & $64,50^{ \pm 0,14}$ \\
\hline
\end{tabular}

Порівнюючи вміст сполук за сортами, очевидно, що у неуражених рослин сорту 'Poliarnyi' вміст флавонолів становив 0,697 мг/г, а в уражених він істотно знижувався до 0,268 мг/г; у неуражених рослин сорту 'Mohuchii' $0,729 \mathrm{мг} / \Gamma$ знижувався до 0,354 мг/Г в уражених, у неуражених рослин сорту 'Holubka' 0,644 мг/Г до 0,375 мг/г в уражених. Варто зазначити, що дані про рівень біохімічних показників у сортів 'Fujiyama' та 'Detstvo' відсутні, оскільки вони були неуражені збудником борошнистої роси (табл. 2).

Табл. 2. Кількісний вміст флавонолів, катехінів та антоціанів у рослин Phlox paniculata, уражених збудником борошнистої роси

\begin{tabular}{|c|c|c|c|}
\hline Сорт & $\begin{array}{c}\text { Сумарний } \\
\text { вміст флавоно- } \\
\text { лів, мг/г (суха } \\
\text { вага) }\end{array}$ & $\begin{array}{c}\text { Вміст катехі- } \\
\text { нів, мг/100 г } \\
\text { сухої речовини }\end{array}$ & $\begin{array}{c}\text { Вміст антоці- } \\
\text { анів, мг/100 г } \\
\text { сухої речовини }\end{array}$ \\
\hline 'Katharine' & $0,408^{ \pm 0,008}$ & $141,00^{ \pm 3,06}$ & $78,00^{ \pm 0,14}$ \\
\hline 'Panianka' & $0,472^{ \pm 0,007}$ & $81,00^{ \pm 1,82}$ & $55,50^{ \pm 0,13}$ \\
\hline 'Tenor' & $0,429^{ \pm 0,010}$ & $96,00^{ \pm 2,14}$ & $93,00^{ \pm 0,21}$ \\
\hline 'Poliarnyi' & $0,268^{ \pm 0,004}$ & $138,00^{ \pm 2,93}$ & $84,00^{ \pm 0,20}$ \\
\hline 'Fiosin' & $0,483^{ \pm 0,009}$ & $117,00^{ \pm 2,52}$ & $81,00^{ \pm 0,18}$ \\
\hline 'Mohuchii' & $0,354^{ \pm 0,005}$ & $150,00^{ \pm 3,12}$ & $93,00^{ \pm 0,19}$ \\
\hline 'Rembrandt' & $0,386^{ \pm 0,007}$ & $111,00^{ \pm 2,08}$ & $84,00^{ \pm 0,17}$ \\
\hline 'Holubka' & $0,375^{ \pm 0,004}$ & $111,00^{ \pm 2,26}$ & $64,50^{ \pm 0,14}$ \\
\hline 'Novinka' & $0,493^{ \pm 0,011}$ & $159,00^{ \pm 3,44}$ & $78,00^{ \pm 0,18}$ \\
\hline
\end{tabular}

Загалом важливо підсумувати, що уражені збудником борошнистої роси рослини Phlox paniculata вирізнялися істотно нижчим вмістом флавонолів, порівняно iз неураженими (у межах від 8,0 до 61,55 \%). Очевидно, що флавоноли витрачалися під час реакцій відновлення антоціанів та катехінів.

Катехіни - це найвідновлюваніші флавоноїди. Їх характерною особливістю $є$ здатність утворювати ефіри із галовою кислотою, яка є мономером гідролізованих танінів [7, 22]. Катехіни поширені у рослинному світі, існують у вигляді безбарвних кристалічних сполук, добре розчинних у воді та багатьох органічних розчинниках (спирти, ацетон, діоксан, етилацетат). Катехіни містяться у багатьох плодах, у корі та деревині багатьох дерев. Сполукам властива висока біологічна активність, зокрема вони сприяють проникненню вітаміну Р в організм тварин та людини [7, 11, 12, 19, 22].

Щодо кількісного вмісту катехінів, то серед неуражених рослин найнижчі показники відзначено у сорту 'Tenor' - 51 мг/100 г сухої речовини, найвищі - у сорту 'Detstvo' - 147 мг/100 г. Показники інших сортів змінювалися в межах 75-138 мг/100 г (див. табл. 1). У рослин, уражених збудником борошнистої роси, кількість катехінів варіювала від $81 \mathrm{mг} / 100$ г у сорту 'Panianka' до 159 мг/100 г у сорту 'Novinka' (див. табл. 2).

Зокрема, у неушкоджених рослин сорту Tenor кількість катехінів становила 51,00 мг/100 г, натомість в ушкоджених вона істотно збільшилась і становила 96,00 мг/100 г; у неушкоджених рослин сорту 'Poliarnyi' становила $114,00 \mathrm{Mr} / 100$ г, а в ушкоджених 138,00 мг/100 г, і насамкінець, у неушкоджених рослин сорту 'Novinka' 138,00 мг/100 г, в ушкоджених 159,00 мг/100 г сухої речовини відповідно.

Отже, внаслідок здійснених досліджень виявлено тенденцію до значного збільшення вмісту катехінів загалом на 8-21\% в уражених борошнистою росою рослин, порівняно із неураженими.

Антоціани є основними пігментами рослин, що дає їм змогу слугувати атрактантами під час запилення квітів та розповсюдження плодів. Саме антоціани забезпечують різноманіття забарвлення квітів, плодів і листків у рослинних організмах. Вони беруть участь в окисновідновних процесах, про що свідчить висока інтенсивність дихання в антоціановмісних рослин. Разом із аскорбіновою кислотою антоціани здійснюють антиоксидантну функцію. Вони виконують функції захисних пігментів, які за потреби екранують клітини мезофілу листка від впливу сонячного світла. Наявність антоціанів сприяє інтенсивному поглинанню сонячної енергії. Окрім цього, за умов стресу часто спостерігається червоне забарвлення листків унаслідок підвищеного вмісту антоціанів [7].

Антоціани відіграють важливу роль у пасивному та активному імунітеті рослин до хвороб. У рослинних тканинах антоціани присутні виключно у формі глікозидів, є непластидними пігментами, у клітині звичайно сконцентровані у вакуолі, де існують у вигляді солей з органічними кислотами $[20,22]$. Серед неуражених рослин Phlox paniculata найвищим вмістом антоціанів відзначився сорт 'Rembrandt' - 72 мг/100 г, найнижчим 'Holubka' - 45 мг/100 г. Інші показники варіювали в межах від 52,5 мг/100 г ('Poliarnyi') до 66 мг/100 г ('Novinka', 'Fiosin', 'Tenor') (див. табл. 1). У рослин, уражених збудником борошнистої роси, найбільше антоціанів (93 мг/100 г) відзначено у сортів 'Mohuchii' i 'Tenor', найменше (55,5 мг/100 г) - у сорту 'Panianka'. Інші copти мали проміжні значення на рівні 64,5-84,0 мг/100 г (див. табл. 2). 
Під час порівняння вмісту антоціанів у представників одного сорту виявлено таку тенденцію: у неуражених рослин сорту 'Katharine' кількість антоціанів підвищувалась на $23,8 \%$ порівняно 3 ураженими; у 'Rembrandt' - на 16,7\%, у 'Holubka' - 43,3 \%, у 'Mohuchii' - на 47,6 \% відповідно. Загалом вміст антоціанів на $18-48$ \% в уражених рослин Phlox paniculata був вищим, ніж у неуражених.

Варто зазначити, що чіткої залежності між вмістом катехінів, антоціанів та флавонолів немає. Це можна пояснити тим, що вміст цих сполук перебуває у стані хімічної рівноваги. Катехіни - це відновлена форма флавоноїдів, антоціани - більш окислена форма. Найбільш окислена форма - це флавоноли. Зміщення рівноваги у бік тієї чи іншої сполуки залежить від багатьох факторів: кислотність, інтенсивність освітлення тощо [3]. Але здійснені дослідження підтвердили той факт, що антоціани, катехіни та флавоноли можна розглядати як екологічні маркери рослин, які беруть участь у пристосувальних реакціях рослинного організму.

Виявлено, що вміст проліну у досліджених рослин Phlox paniculata перебував у межах від 0,006 ммоль/мл у неуражених рослин сорту 'Rembrandt' до 0,034 ммоль/мл у неуражених рослин сорту 'Panianka' (рисунок).

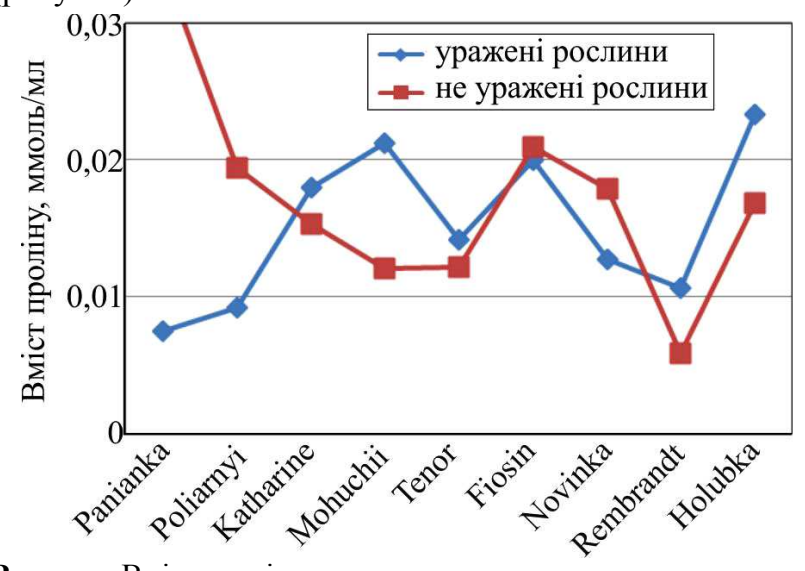

Рисунок. Вміст проліну в уражених та неуражених рослин Phlox paniculata

В уражених рослин цей показник варіював від 0,008 ммоль/мл у сорту 'Panianka' до 0,023 ммоль/мл у copту 'Holubka'. На цей показник, вірогідно, впливав збудник борошнистої роси, призводячи рослини до стану певного стресу. Рівень цього стресу пов'язаний із сортом та стійкістю рослин та проявлявся у зміні вмісту вторинних метаболітів. Проте істотної залежності між вмістом проліну та ступенем ураження рослин Phlox paniculata не виявлено, що потребує додаткових досліджень у майбутньому.

Отже, за результатами дослідження біохімічних показників в уражених та неуражених збудником борошнистої роси листків рослин Phlox paniculata можна зробити висновок, що ураження грибною інфекцією призводить рослини до стресу, враховуючи механізм захисту рослин, за якого змінюється вміст вторинних метаболітів. Лабораторні експерименти буде продовжено у різні періоди вегетації з урахуванням фенологічних фаз.

Висновки. Внаслідок виконання роботи було досліджено біохімічні показники у листках рослин Phlox paniculata L., уражених і неуражених збудником борошнистої роси (Erysiphe cichoracearum DC.f. phlogis Jacz.) в умовах Лісостепу України. За результатами виконання роботи можна зробити такі основні висновки:

1. Рослини, уражені збудником борошнистої роси, характеризувалися нижчим рівнем флавонолів (сорти 'Poliarnyi' - 0,268 мг/г, 'Mohuchii' - 0,354 мг/г), неуражені вищим вмістом флавонолів (сорти 'Detstvo', та 'Mohuchii'). Отже, можна зробити висновок, що вміст флавонолів є маркером стійкості рослин до ураження збудником борошнистої роси.

2. Виявлено тенденцію до істотного збільшення вмісту катехінів загалом на 8-21 \% в уражених борошнистою росою рослин, порівняно із неураженими.

3. Відзначено певну закономірність щодо вмісту антоціанів: в уражених рослин він був на 18-48 \% вищим, ніж у неуражених.

4. Виявлено, що рівень проліну істотно не залежить від ступеня ураженості рослин Phlox paniculata збудником борошнистої роси, оскільки в цьому механізмі захисту рослин від стресу, спричиненого збудником борошнистої роси (Erysiphe cichoracearum DC. f. phlogis Jacz.), діє механізм із застосуванням вторинних метаболітів.

\section{References}

1. Andreyeva, V. Yu. (2000). Development of a method for the flavonoids quantitative determination in a cuff ordinary Alchemilla vulgaris L.s.l. Chemistry of plant raw material 1, 85-88. [In Russian].

2. Butenkova, A. N. (2014). Biological features of species and varieties of the phlox genus (Phlox L., Polemoniaceae) in the subzone of the southern taiga of Western Siberia. Doctoral Dissertation for Philosophy Science (03.02.01 - Botany), 185 p. [In Russian].

3. Cherviakovskiy, Ye. M., Kucherenko, V. P., \& Kostiuk, V. A. (2009) The role of flavonoids in biological reactions with electron transfer. Proceedings of the Belarusian State University. Series of Physiological, Biochemical and Molecular Biology Sciences, 4(1), 9-26. [In Russian].

4. Dishuk, N. U., \& Gaishun, V. V. (2016). Phlox diseases in the Central Botanical Garden of the National Academy of Sciences of Belarus. Floriculture: history, theory, practice: Proceedings of the VII International Scientific Conference, 393-394. [In Russian].

5. Gleason, H. A. (1952). The new Britton and Brown illustrated Flora of the northeastern United States and adjacent Canada. New York: Lancapter Press, Vol. 3, pp. 94-100.

6. Hogan, S. (2003). Flora. A gardeners encyclopedia. Portland, Oregon: Timber Press, Inc., Vol. 2, 1028-1030.

7. Kobyletzka, M. N., \& Terek, O. I. (2017). Plant biochemistry. Lviv: IFNUL, 269 p. [In Ukrainian].

8. Konstantinova, Ye. A. (2002). The Phloxes. Moscow: "Phiton+", 192 p. [In Russian].

9. Kriventzov, V. I. (1982). Methodical recommendations for the analysis of fruits for biochemical composition. Yalta: SNBG, 192 p. [In Russian].

10. Kudusova, V. L. (2014). History and current status of a collection of fall phlox varieties (Phlox paniculata L.) in the Main Botanical Garden named after N. V. Tsitsin RAS. "Phlox-2014": Proceedings of the All-Russian scientific-practical conference, 77. [In Russian].

11. Levchyk, N. Ya., Skrypka, G. I., Levon, V. F., \& Horbenko, N. Ye. (2018). Accumulation of flavonoids in Phlox paniculata L. plants under the conditions of the Forest-Steppe of Ukraine depending on exogenous factors. Fundamental and applied aspects of plant introduction in the realities of European integration: Proceedings of the Scientific-Practical Conference, 203-205. [In Ukrainian].

12. Levchyk, N. Ya., Skrypka G. I., Levon, V. F., Liubinska, A. V., \& Horbenko, N. Ye. (2018). Content of flavonoids in Phlox paniculata L. plants in the Forest-Steppe zone of Ukraine. Scientific Bulletin of UNFU, 28(3), 38-42. https://doi.org/10.15421/40280308 
13. Levchyk, N. Ya., Skrypka, G. I., Liubinska, A. V., \& Zakrasov, O. V. (2018). Level of proline in the Phlox paniculata L. plants in conditions of the Forest-Steppe of Ukraine. Advances in Botany and Ecology: Proceedings of the International Conference of Young Scientists, 87. [In Ukrainian].

14. Levishko, A. S., Mamenko, P. M., \& Kots, S. Ya. (2014). Plant metabolomics: fundamentals and role in the study of plant-microbe interactions. Plant Physiology and Genetics, 46(1), 19-26. [In Ukrainian].

15. Locklear, J. H. (2011). Phlox: a natural history and gardeners guide. Portland, Oregon: Timber Press, Inc., $304 \mathrm{p}$.

16. Musienko, M. M. (2001). Plant physiology: Manual. Kyiv: Fitosotziotzentr, 392 p. [In Ukrainian].

17. Richard, G., \& Hawke, A. (2011). Comparative Study of Phlox paniculata cultivars. Plant Evaluation Notes, Chicago Botanic Garden, Iss. 35, 1-10.

18. Shihalyeyeva, G. N., Budnyak, A. K., Shihalyeyev, I. I., \& Ivaschenko, O. L. (2014). A modified method for determination of proline in plants. The Journal of $V$. N. Karazin Kharkiv National University. Series: biology, 21(1112), 168-172. [In Russian].

19. Skrypka G. I., Levchyk, N. Ya., Levon, V. F., \& Liubinska, A. V. (2019). Quantification of catechins in the aboveground organs of Phlox paniculata L. plants in the conditions of the Forest-Steppe of Ukraine. Proceedings of the Scientific Conference devoted to $90^{\text {th }}$ Anniversary of T. M. Cherevchenko, 228-229. [In Ukrainian].

20. Skrypka G., Levchyk, N., \& Levon, V. (2018). The content of anthocyanins in the aboveground organs of Phlox paniculata $\mathrm{L}$. plants in the conditions of the Forest-Steppe of Ukraine. Modernization of the national system of state development management: Proceedings of the III International Scientific-Practical Conference, 60-61. [In Ukrainian].

21. Takhtajan, A. (2009). Flowering plants (2nd ed.). Springer science + Business Media V. P., 871 p.

22. Zaprometov, M. N. (1974). Fundamentals of biochemistry of phenolic compounds. Moscow: Vyshchaya shkola, 213 p. [In Russian].

N. Ya. Levchyk', H. I. Skrypka1, V. F. Levon', O. V. Zakrasov', N. Ye. Horbenko²

${ }^{1}$ M. M. Gryshko National Botanical Garden, NAS Ukraine, Kyiv, Ukraine

${ }^{2}$ Ukrainian National Forestry University, Lviv, Ukraine

\section{THE CONTENT OF BIOCHEMICAL SUBSTANCES IN PHLOX PANICULATA L. PLANTS LEAVES IN THE FOREST-STEPPE ZONE OF UKRAINE}

The article represents the comprehensive study of the resistance of ornamental plants Phlox paniculata L. to the biotic stress caused by the causative agent of powdery mildew (Erysiphe cichoracearum DC.f. phlogis Jacz.). The aim of the study was to investigate biochemical parameters in leaves of plants with different degree of resistance to the damage. in the conditions of the Forest-Steppe of Ukraine. There were classic common methods of determining the content of anthocyanins, catechins, proline, flavonoids applied in this work study. The varieties of fall phlox were studied: 'Katharine', 'Panianka', 'Tenor', 'Poliarnyi', 'Fiosin', 'Mohuchii', 'Rembrandt', 'Holubka', 'Novinka', 'Fujiyama', 'Detstvo'. The main result of the experiments is to establish a mechanism for the secondary metabolites use (catechins, flavonoids and anthocyanins) in the process of the increased plant resistance formation. As a result, the content of flavonoids is significantly reduced, in the affected plants, and the content of catechins and anthocyanins is significantly increased compared with the intact ones on the contrary. It is noted, that the content of flavonols in plants with powdery mildew is significantly lower in comaprison with unaffected plants from 8.0 to $61.55 \%$. The flavonols are obviously consumed during anthocyanins and catechins recovery reactions. In addition, there is a tendency for a significant increase in the content of the catechins in the affected powdery mildew plants compared to the non-affected ones generally $8-21 \%$. The anthocyanin content in the affected plants was also higher on $18-48 \%$. Therefore, studies represent that the content of secondary metabolites is a marker of Ph. paniculata plants stability to the cause of powdery mildew unlike proline.

Keywords: Phlox paniculata L. - fall phlox, causative agent of powdery mildew; proline; catechins; flavones; flavonols; anthocyanins; resistance. 